\title{
What Is the Role of the Vendor in Modern Elections?
}

\author{
Mindy Perkins
}

\begin{abstract}
The election official is the voice of integrity in election administration. They represent the process when elections go wrong and when they go right. Many people and groups help support the process including political parties, nonprofit groups, and vendors. This case focuses on the vendor's perspective of the elections process and how integral it is to incorporate vendor voices into election administration. Communication between vendors and state and local election offices leads to successful partnerships and to successful elections. It is essential that the vendor community be viewed as a subset of the larger elections community. Communication is key for election officials to be able to trust the outcome, and trust in the outcome inspires confidence in voters and stakeholders across the process.
\end{abstract}

Keywords Vendors • Vendors instrumental in elections community

- Customer focus • Nonpartisan • Integrity

M. Perkins $(\bowtie)$

VR Systems, Inc., Tallahassee, FL, USA

e-mail: mperkins@vrsystems.com

(C) The Author(s) 2019

M. Brown et al. (eds.), The Future of Election Administration, Elections, Voting, Technology, https://doi.org/10.1007/978-3-030-18541-1_10 


\section{CONTEXT}

I have been in elections as a vendor since April of 2001 which means that in my 18 years of elections, I have seen many highs and lows. I experienced the aftermath of the 2000 election firsthand while living in Tallahassee, Florida. Our capital city downtown was inundated with speed bumps made up of cables from the news trucks on roads in front of the Florida Supreme Court building. Our small city was overwhelmed with media from all over the world. This was before I worked in elections and little did I know that nearly three months later, I would begin a career of supporting integrity in the elections process.

The election official is the voice of integrity in elections administration. Voters trust elections because they trust their local election official. The local election official is the voice when something goes wrong but many people and groups help support the process from political parties and nonprofit groups to vendors. I will share a vendor's perspective on the elections process and how integral it is to incorporate our voice into election administration.

\section{Setting The Stage}

Vendors are crucial for the election community. And yet it is challenging to be a leader in elections because of the spotlight, which has only increased since 2000. We have insights and information that must be heard. However, much of the election community is cautious and isn't interested in leading edge technology-it's too risky and usually costly. Election vendors are concerned that they are only seen as greedy and money-hungry rather than doing what is in the best interest of the community. The election community is close-knit with a small number of vendors competing for business. There are very few secrets in the elections vendor community and news spreads when a vendor doesn't support their customers.

Very few election administrators or vendors went to school for election administration-higher education in the field is too new. Our career paths have led us here and once elections get into your blood, it is hard to say goodbye. Since my start with elections, election administration has become much more professionalized both on the administrator side and for the vendor community. Administrators are held to a high standard to protect the vote, and there is significant scrutiny of whom they partner with. This is important and should be encouraged. Jurisdictions are less likely to partner with an unproven vendor. There is too much at risk, and every single vote must be protected. 


\section{Details}

VR Systems (VR) was founded in 1992, more than 25 years ago, to serve Florida counties needing an affordable, modern, voter registration system. Florida counties weren't being served by the other voter registration vendors and the systems they had were out-of-date and/or otherwise didn't meet their needs. The founders of VR Systems, Jane and David Watson, built a system that met the needs of those underserved counties. As the need for more modern systems grew, so did the company.

VR has been shaped and influenced by several historical events. Following the 2000 election, Congress passed the Help America Vote Act (HAVA) to fund the modernization of elections. Florida was at the forefront of that initiative and a leader among states in the transition. At the time, VR offered its flagship product, Voter Focus, which is a comprehensive elections management software system for voter registration. VR expanded rapidly to meet the state's technology needs and was highly successful. Together, in just 18 months, founder Jane Watson and I successfully onboarded over 35 new Voter Focus counties in Florida out of its 67 counties.

VR's electronic pollbook EViD was later developed in response to powerful Category 4 Hurricane Charley which wiped out precincts in Southwest Florida just weeks before a primary election. The $145-\mathrm{mph}$ winds and rain caused $\$ 6.755$ billion in damages in Florida alone.

The devastation across the region was massive and thousands of people were displaced. The challenges facing the affected counties were both significant and numerous. The following illustrates some of the conditions that VR encountered in Charlotte County and Hardee County, and how we responded.

In Charlotte County, despite the fact that the homes of many election office staff were harmed or destroyed by the hurricane, people reported to work because they knew the election couldn't be delayed. Governor Jeb Bush declared an election emergency that gave counties affected by the hurricane the administrative operating flexibility they needed to meet the needs of residents. That included combining precincts if a building was destroyed and the ability to move polling places. Because so many voting locations were ravaged by the storm, Charlotte County had to cut its precinct polling places from 80 to 22 ; within these 22 were 9 consolidated "super precincts." The existing paper pollbooks that listed the voters at specific polling places would not meet the needs in this chaotic environment. The election office needed a tool that would allow voters in Charlotte 
County to vote at any polling place in the county—not just the precinct to which they had been assigned. Some of the consolidated precincts had as many as 10,000 voters assigned to them which could have created a nightmare for poll workers on Election Day. Charlotte County officials expressed fears that they would never be able to handle the crowds at the super precincts with conventional methods.

VR Systems was asked if there was anything we could do to help. We have always thought of ourselves as an extension of an election office and this time was no different. If there was anything we could do to help, we were going to do it. We quickly analyzed what the pollbook system requirements were and identified the problems that needed to be solved. Most important, the system needed to check-in voters as efficiently and accurately as possible. We worked closely with the county and in less than a week, we delivered a device that would allow voters to be checked in on a laptop rather than the paper pollbooks that were in use at the time.

Two of VR's lead developers traveled to Charlotte County to set up and train staff and poll workers on the voter check-in system that would be used during the primary election. The election staff and poll workers were trained on the new system in a short period of time. We worked tirelessly, along with the entire election office, to help conduct a successful election.

The new system worked well and allowed voters to retain their right to vote in the new precinct structure, despite the tragic circumstances that surrounded them. And out of this tragedy came innovation. The system that VR crafted would become the EViD electronic voter check-in system that many counties use today. Following that successful election, the electronic pollbook EViD was patented and today more than 15,000 EViDs are used in major elections across the country.

One of the other counties tragically affected by Hurricane Charley was Hardee County which is home to Arcadia, Florida. Hardee County lost half of its voting locations and $75 \%$ of its county residences. The county was left with more than $\$ 750$ million in damage. In addition to the physical losses the county suffered, it also suffered the loss of its top election official, Dean Cullins, to a heart attack two days after the hurricane. Hardee County is a small county with only a few staff members so their needs were smaller in scale but no less important. They needed help prepping for the election since their tiny office staff size was reduced by one-third. Two of our employees drove down to Hardee County to help in any way they could. For quite some time the county was without a Supervisor of 
Elections (the elected county official responsible for election operations) and basic functions could not be performed. VR staff were quickly deputized so that they could help run the election. They returned absentee ballots and registered voters, all with no air-conditioning or comforts. Because we had so many staff helping in the counties, it left only a few people to help all of our other customers in Tallahassee. Despite these and other challenges, we all pitched in to ensure that the counties ran elections smoothly.

More recently, as CEO I was called to guide VR through a high-profile news event that directly impacted the company's reputation. In 2017, a defense contractor employee leaked a confidential document that depicted VR as the subject of a Russian phishing attack. VR was not compromised as a result of this attack. However, the following weeks, months, and years brought tremendous international scrutiny to the company. We worked tirelessly directing a crisis response team to communicate information concerning the nature of the attempt as accurately and transparently as possible.

VR has stepped into the role of an elections cybersecurity leader, serving on a US Department of Homeland Security (DHS) executive committee and implementing a cybersecurity communications education program to share VR's experience with election officials around the country. In addition, the company has launched its own internal cybersecurity program, recently becoming the first vendor to successfully complete both DHS risk and vulnerability assessment (RVA) and Hunt testing which provides assistance to potentially impacted entities, analyzes the potential impact across critical infrastructure, investigates those responsible in conjunction with law enforcement partners, and coordinates the national response to significant cyber incidents (Department of Homeland Security ND). ${ }^{1}$

\section{Implications of Changing Technology}

The promises and limits of technology are very apparent in the election community and where the needs and desires of election administrators come face-to-face with what is possible in equipment used in conducting elections. Election administration is a niche community with custom-built technologies. What is true but not easy to see is that, often, technology in one sector would not work in another.

\footnotetext{
${ }^{1}$ United States Department of Homeland Security. "Cyber Incident Response," accessed February 27, 2019. https://www.dhs.gov/cisa/cyber-incident-response.
} 
For example, there has been much focus on online voting which would allow the right to vote to be held in every voter's hands. The implication is that since banking can be done online, voting can be done online too. And this is appealing; it would be very user friendly if a voter could simply vote online-this would eliminate the need for polling sites, poll workers, expensive equipment, and so on. But this is a misconception. The primary issue I have with this approach is that every vote is private and must be tallied. Banks lose money each year because of online attacks. In 2017, financial services firms, banks lost $\$ 16.8$ billion to cybercriminals (Mirchandani 2018). ${ }^{2}$ Are we willing to take that gamble with our right to vote? I can't imagine that any voter would be ok with their vote being the one that is lost. Vendors are responsible for delivering solutions that protect every voter's right to vote. Technology does not yet exist that can ensure that all votes would be tallied in the way the voter intended.

There is also tension between all the different expectations we have about voting, and about what we want from voting equipment. There must be a balance between a voter-friendly experience, equipment security, and costs that are reasonable for taxpayers and politicians. If one of those items is out of balance, the system delivers less than expected in some way. It is a constant challenge in the vendor community today to maintain usability and keep support costs low without compromising on security.

It is also important to note that integrity is more than software or hardware security. Part of voter confidence in the outcomes of elections has to do with their belief in the fairness of the process. So, the idea of integrity has to include nonpartisan attitudes and practices. Voters may care about political parties and which of their candidates won or lost, but vendors cannot show preference or favoritism of any kind in the work that we do.

\section{REFLECTIONS}

No matter the technology requirements and changes, personal relationships are key. Strong relationships between vendors and election offices are the cornerstone to successful elections. Communications between vendors and offices lead to successful partnerships and to successful elections. Communication is key for election officials to be able to trust the out-

\footnotetext{
${ }^{2}$ Mirchandani, Bhakti. "Laughing all the way to the bank: Cybercriminals targeting U.S. financial institutions," Forbes, August 28, 2018, https://www.forbes.com/sites/bhaktimirchandani/2018/08/28/laughing-all-the-way-to-the-bank-cybercriminals-targeting-usfinancial-institutions/\#24e90c856e90.
} 
come, and trust in the outcome inspires confidence in voters and stakeholders across the process.

It is also essential that the vendor community be viewed as a subset of the larger elections community. We are often viewed as outsiders who only know very basic information and that we only need to know what we are told. Vendors have broad perspectives that are often disregarded because of our role in "selling widgets." I believe that without vendors' input and participation, only part of the story is told. It is critical to hear the wide variety of voices and for us to do what we can to better the election community, and this is only possible with communication and trust. For example, election officials often ask us our opinion about the best way to perform a task since we glean inputs from a wide variety of customers. As another example, the term "voting systems" is widely considered to mean vote tabulation systems, but not other types of equipment used in elections. The voting environment uses many kinds of equipment that are not tabulators, and vendors of these other types of equipment have a unique perspective that encompasses the broad spectrum of election administration.

As a voter registration and electronic pollbook vendor, VR Systems has a unique perspective that encompasses this broad spectrum and I am confident that VR will continue to pursue its work in finding solutions for election administrators. We trust that our customer focus demonstrates commitment under extremely challenging circumstances, and that our commitment to integrity demonstrates our service to our customers and to election administrators everywhere.

Open Access This chapter is licensed under the terms of the Creative Commons Attribution 4.0 International License (http://creativecommons.org/licenses/ by $/ 4.0 /)$, which permits use, sharing, adaptation, distribution and reproduction in any medium or format, as long as you give appropriate credit to the original author(s) and the source, provide a link to the Creative Commons licence and indicate if changes were made.

The images or other third party material in this chapter are included in the chapter's Creative Commons licence, unless indicated otherwise in a credit line to the material. If material is not included in the chapter's Creative Commons licence and your intended use is not permitted by statutory regulation or exceeds the permitted use, you will need to obtain permission directly from the copyright holder.

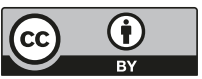

